Liston, J. (1956). J. gen. Microbiol. 15, 305-314

\title{
Quantitative Variations in the Bacterial Flora of Flatfish
}

\author{
By J. LISTON \\ Torry Research Station, Aberdeen
}

\begin{abstract}
SUMMARY : Bacterial counts made, over a period of 27 months, on skin, gut and gill samples of freshly caught skate and lemon sole, using sea water-based and tap waterbased media in parallel, revealed a seasonal variation in the size of the bacterial populations on the fish throughout the year. Evidence is presented for the view that the occurrence of maximum bacterial populations on fish is correlated with plankton outbursts. Sea water-based medium was generally superior to a tap water-based medium for isolating bacteria from fish; the importance of this as evidence of a specific marine bacterial flora is discussed.
\end{abstract}

Bacteria occur in appreciable numbers on the skin and gills and in the intestinal contents of fish (Harrison, Perry \& Smith 1926). However, it is generally accepted that the internal organs and the muscle tissues of (healthy) live or freshly caught fish are sterile (Anderson, 1907; Proctor \& Nickerson, 1935). The spoilage of fish as a foodstuff is due to the activities of bacteria normally present on the living fish which, after the animal's death, penetrate into the muscle tissues and decompose them. Consequently, the bacterial flora of different types of fish has been the subject of several investigations, the results of which were summarized by Shewan (1949). Most of these studies were confined to commercially important species of 'round' fish' such as cod, haddock and herring and have, in the main, consisted of qualitative analyses of the bacterial types isolated from them; flatfish such as skate, lemon sole, turbot, etc., have been little studied. However, the results of an investigation by Reay \& Shewan (1949) into the numbers of bacteria on the skin of haddock at various times of the year indicated that there is probably a seasonal variation in the quantitative load of bacteria on this fish. This conclusion is not entirely unexpected since seasonal variations in the numbers of bacteria in sea water have been observed by workers in different parts of the world (Lloyd, 1930; ZoBell $\&$ McEwan, 1935; Wood, 1953) and sea water is undoubtedly the source of many of the bacteria found on fish.

Workers in the field of marine bacteriology have used a variety of media in investigations of the bacterial flora of sea water and of fish and this has made comparison of their results peculiarly difficult. Since it has been claimed that many bacteria of marine origin will not grow in the absence of sea water (ZoBell, 1946) the comparison of viable counts made in tap-water-containing and sea water-containing media is particularly difficult.

The investigation described below was carried out to determine whether seasonal variations occur in the bacterial flora of skate (Raja spp.) and lemon sole (Pleuronectes microcephalus) and to determine, so far as possible, what proportion of the bacteria on the fish require sea water in the media for their

G. Microb. xv 
growth, by comparing the results of viable counts obtained with sea-water media and fresh-water media. Skate and lemon sole were chosen as the subjects of this investigation for three reasons: (1) very little has been published concerning the bacterial flora of flatfish, the mode of life of which differs from that of the more free-swimming 'round' fish; $(2)$ though they occupy the same environment and have a similar mode of life the two fish belong to different taxonomic groups; the skate is an elasmobranch while the lemon sole is a teleost; (3) both fish are readily obtainable in Aberdeen Bay all the year round.

\section{METHODS}

During the period October 1952 to December 1954 several freshly caught specimens of lemon sole and skate were examined each month. The fish were caught by trawl net some 10 miles off-shore in Aberdeen Bay. They were transferred from the net to sterile aluminium boxes with the minimum of handling and brought to the laboratory within a few hours of catching. During transit the boxes were surrounded with ice and the fish were frequently still alive on reaching the laboratory. On arrival they were killed when necessary, and skin samples of known uniform area and weighed gut and gill samples excised. Duplicate viable counts were carried out on the diluted samples using tap water-based media and sea-water-based media in the usual pour-plate technique.

Tap water-based medium (horse heart agar; HHA) contained $0.5 \%$ sodium chloride, $1.0 \%$ peptone and $1.5 \%$ agar dissolved in a tap water extract of horse or ox heart (500 g. minced lean heart/1000 ml. water).

Sea water-based medium (sea water agar; SWA) contained 0.1\% LabLemco, $0.1 \%$ peptone, $0.1 \%$ glucose, $0.005 \%$ potassium phosphate and $1.5 \%$ agar dissolved in sea water. The sea water was previously aged by storing it in a glass container in the dark for several weeks to eliminate the intrinsic bacteriostatic property of raw sea water (ZoBell, 1946).

Both media were sterilized by autoclaving at $15 \mathrm{lb}$./sq.in. $\left(c .121^{\circ}\right)$ for $15 \mathrm{~min}$. and the reaction adjusted to give a $\mathrm{pH}$ value after autoclaving of $\mathbf{7 \cdot 6}$.

In each count, duplicate series of plates were incubated at $20^{\circ}$ and $0^{\circ}$ and the resulting colonies counted after 5 and 25 . days, respectively. A few plates inoculated from the original suspension were incubated at $37^{\circ}$ and counted after 3 days of incubation. These latter served primarily as a control of the counting technique since few organisms from fish caught in Northern waters will grow at temperatures greater than $30^{\circ}$ (Schönberg, 1930).

\section{RESULTS}

The number of fish examined each month is shown in Table 1. The results of the counts carried out each month have been averaged and, for convenience of presentation (in view of the fluctuations from fish to fish), are recorded as the logarithm to the base ten of the number of bacteria $/ \mathrm{cm} .{ }^{2}$ skin sample or $/ \mathrm{g}$. gut or gill samples. 
Plates incubated at $37^{\circ}$ rarely developed more than a few colonies and in no case did the count at this temperature exceed $3 \%$ of that at $20^{\circ}$. The values obtained for bacterial counts carried out at incubation temperatures of $0^{\circ}$ and $20^{\circ}$ are listed in Tables 2 and 3 and in Figs. 1-6 respectively.
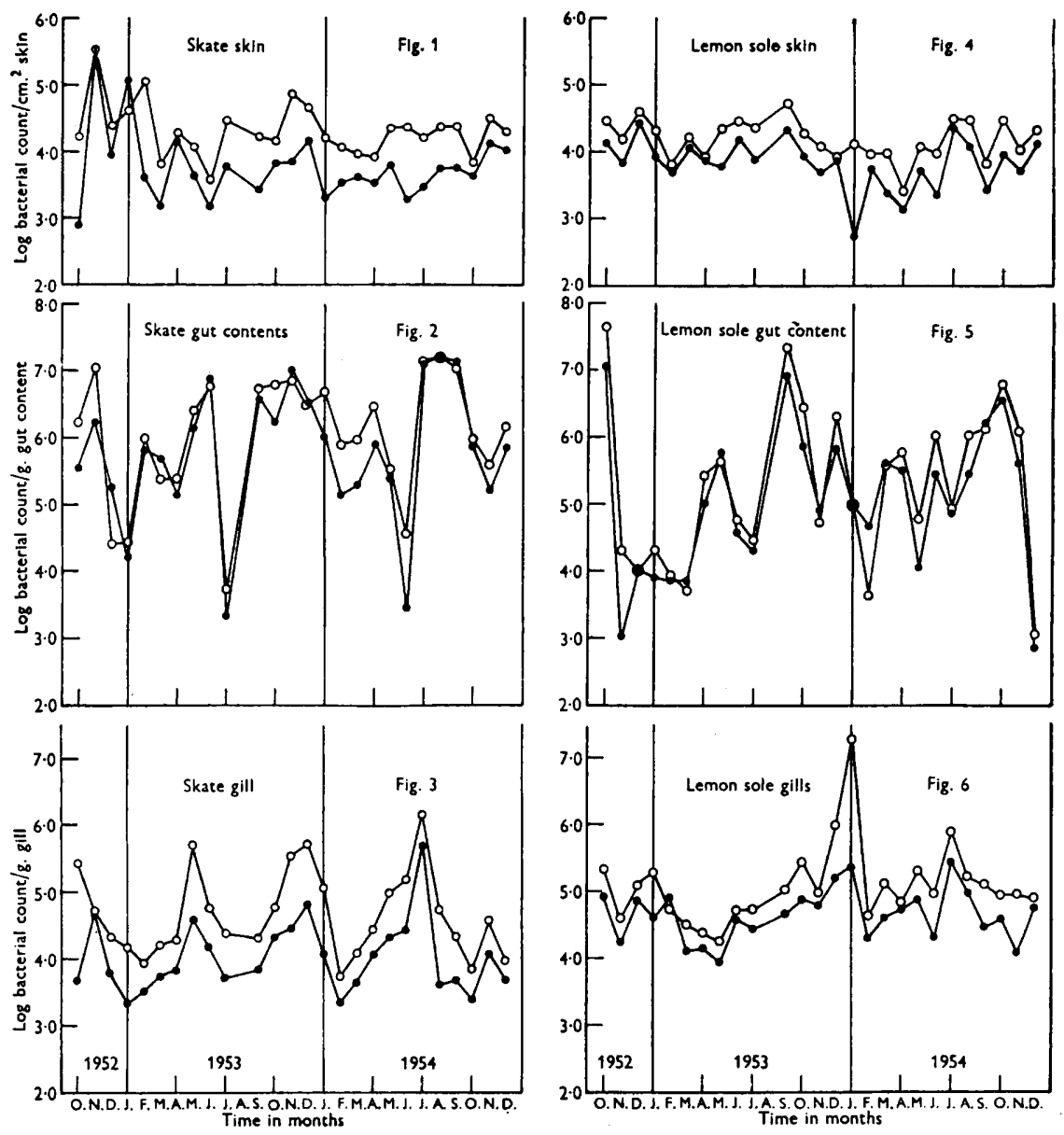

Figs. 1-3. Bacterial counts $\left(20^{\circ}\right)$ in skate skin, gut contents and gills. Each point represents the average of one month's results - $-\mathrm{O}_{-}$, counts using sea water agar (SWA); - , counts using tap water agar (HHA).

Fig. 4-6. Bacterial counts $\left(20^{\circ}\right)$ on Lemon sole skin, gut contents, gills. Each point represents the average of one month's results $-\mathrm{O}-\mathrm{O}$, counts using SWA; counts using HHA.

In general it appears from the $20^{\circ}$ counts that the numbers of viable bacteria on the skin of freshly caught skate and lemon sole vary between $10^{3}$ and $10^{5}$ organisms $/ \mathrm{cm}^{2}$ On the gills the range is between $10^{3}$ and $10^{6} \mathrm{organisms} / \mathrm{g}$. for skate and between $10^{4}$ and $10^{6}$ organisms $/ \mathrm{g}$. for lemon sole. The numbers of living bacteria in gut samples from both fish varied from $10^{3}$ to $10^{7}$ organisms/g. 
Table 1. Number of fish examined each month during period October (O.) 1952 to December (D.) 1954

Year...

1952

1953

\begin{tabular}{|c|c|c|c|c|c|c|c|c|c|c|c|c|c|c|}
\hline Year... & & 1952 & & & & & & & & 953 & & & & \\
\hline & O. & $\mathbf{N}$. & D. & $\mathbf{J}$. & F. & M. & A. & M. & J. & J. & A. & & S. & O. N. D \\
\hline Skate & 2 & 2 & $\mathbf{2}$ & 2 & $\mathbf{3}$ & 3 & $\mathbf{3}$ & 4 & 6 & $\mathbf{2}$ & - & & 4 & 4 \\
\hline Lemon Sole & 2 & 2 & 2 & 3 & 2 & $\dot{\mathbf{3}}$ & $\mathbf{3}$ & 4 & 6 & 2 & - & & 4 & 4 \\
\hline Monthly total & 4 & 4 & 4 & 5 & 5 & 6 & 6 & 8 & 12 & 4 & - & & 8 & 10 \\
\hline Year... & \multicolumn{12}{|c|}{1954} & & \multirow{2}{*}{$\begin{array}{c}\text { Total } \\
\text { samples }\end{array}$} \\
\hline & J. & F. & M. & A. & M. & $\mathbf{J}$. & $\mathbf{J}$. & A. & S. & o. & N. & D. & & \\
\hline Skate & 1 & $\mathbf{3}$ & 4 & 6 & 5 & 2 & $\mathbf{3}$ & $\mathbf{3}$ & 4 & $\mathbf{5}$ & 5 & 3 & & 90 \\
\hline Lemon Sole & 1 & $\mathbf{3}$ & 4 & 6 & 5 & 2 & 3 & $\mathbf{3}$ & 4 & $\mathbf{5}$ & 5 & 3 & & 90 \\
\hline Monthly total & $\mathbf{2}$ & 6 & 8 & 12 & 10 & 4 & 6 & 6 & 8 & 10 & 10 & 6 & & 180 \\
\hline
\end{tabular}

Table 2. Bacterial counts $\left(0^{\circ}\right.$ incubation) from skate samples

\begin{tabular}{|c|c|c|c|c|c|c|}
\hline \multirow{3}{*}{ Month and year } & \multicolumn{2}{|c|}{ Skin count on } & \multicolumn{2}{|c|}{$\begin{array}{l}\text { Gut contents } \\
\text { count on }\end{array}$} & \multicolumn{2}{|c|}{ Gills count on } \\
\hline & HHA & SWA & HHA & SWA & HHA & SWA \\
\hline & $\log c c$ & $/ \mathrm{cm}^{2}$ & \multicolumn{2}{|c|}{$\log$ count/g. } & \multicolumn{2}{|c|}{$\log \operatorname{count} / g$. } \\
\hline Oct. 1952 & $\mathbf{2 \cdot 8 6}$ & $4 \cdot 15$ & $5 \cdot 25$ & $4 \cdot 26$ & $4 \cdot 10$ & $\mathbf{5} \cdot \mathbf{1 6}$ \\
\hline Nov. 1952 & $4 \cdot 82$ & $4 \cdot 83$ & $4 \cdot 28$ & $2 \cdot 48$ & $4 \cdot 19$ & $\mathbf{3} \cdot \mathbf{3 8}$ \\
\hline Dec. 1952 & $3 \cdot 78$ & $4 \cdot 11$ & $4 \cdot 01$ & $3 \cdot 76$ & $\mathbf{3} \cdot 53$ & $4 \cdot 07$ \\
\hline Jan. 1953 & $4 \cdot 07$ & $4 \cdot 19$ & $4 \cdot 31$ & $4 \cdot 64$ & $3 \cdot 14$ & $\mathbf{3} \cdot \mathbf{8 7}$ \\
\hline Feb. 1953 & $3 \cdot 42$ & $3 \cdot 84$ & $5 \cdot 37$ & $5 \cdot 24$ & $\mathbf{3 . 5 5}$ & $3 \cdot 75$ \\
\hline Mar. 1953 & $\mathbf{3 \cdot 0 5}$ & $2 \cdot 90$ & $4 \cdot 93$ & $4 \cdot 84$ & $\mathbf{3 . 5 5}$ & $\mathbf{3} \cdot \mathbf{8 7}$ \\
\hline Apr. 1953 & $4 \cdot 16$ & $4 \cdot 12$ & $5 \cdot 56$ & $4 \cdot 73$ & $4 \cdot 01$ & $3 \cdot 92$ \\
\hline May 1953 & $3 \cdot 73$ & $3 \cdot 99$ & $6 \cdot 02$ & $5 \cdot 39$ & $5 \cdot 30$ & $\mathbf{5} \cdot \mathbf{3 0}$ \\
\hline June 1953 & $\mathbf{3} \cdot 24$ & $\mathbf{3} \cdot \mathbf{5 2}$ & $6 \cdot 83$ & $7 \cdot 06$ & $4 \cdot 26$ & $\mathbf{4 \cdot 5 7}$ \\
\hline July 1953 & $\mathbf{3} \cdot \mathbf{8 4}$ & $\mathbf{3} \cdot \mathbf{8 0}$ & $3 \cdot 87$ & $4 \cdot 41$ & $4 \cdot 28$ & $4 \cdot 85$ \\
\hline Aug. 1953 & - & - & - & - & - & - \\
\hline Sept. 1953 & $3 \cdot 52$ & $4 \cdot 02$ & $6 \cdot 16$ & $5 \cdot 64$ & $\mathbf{3 \cdot 9 0}$ & 3.97 \\
\hline Oct. 1953 & $\mathbf{3 \cdot 6 2}$ & $\mathbf{3 \cdot 8 4}$ & $5 \cdot 92$ & $6 \cdot 71$ & $4 \cdot 14$ & $4 \cdot 26$ \\
\hline Nov. 1953 & $3 \cdot 71$ & $4 \cdot 50$ & $6 \cdot 95$ & 5.01 & $4 \cdot 87$ & $5 \cdot 14$ \\
\hline Dec. 1953 & $4 \cdot 14$ & $4 \cdot 33$ & $5 \cdot 53$ & $5 \cdot 42$ & 4.90 & $5 \cdot 30$ \\
\hline Jan. 1954 & $3 \cdot 05$ & 3.97 & $5 \cdot 67$ & $6 \cdot 36$ & $4 \cdot 81$ & $5 \cdot 12$ \\
\hline Feb. 1954 & $2 \cdot 63$ & $3 \cdot 96$ & $3 \cdot 17$ & $4 \cdot 45$ & $2 \cdot 54$ & $\mathbf{2 \cdot 5 6}$ \\
\hline Mar. 1954 & $\mathbf{3 . 5 3}$ & $\mathbf{3} \cdot \mathbf{8 3}$ & $4 \cdot 88$ & $4 \cdot 93$ & $3 \cdot 40$ & 3.92 \\
\hline Apr. 1954 & $3 \cdot 41$ & $3 \cdot 75$ & $5 \cdot 42$ & $5 \cdot 63$ & $\mathbf{3} \cdot \mathbf{8 1}$ & 4.25 \\
\hline May 1954 & $3 \cdot 61$ & $4 \cdot 23$ & $5 \cdot 22$ & $\mathbf{5} \cdot \mathbf{3 6}$ & $4 \cdot 21$ & $4 \cdot 84$ \\
\hline June 1954 & $2 \cdot 93$ & $4 \cdot 04$ & $\mathbf{3} \cdot 23$ & $4 \cdot 64$ & $4 \cdot 40$ & $4 \cdot 88$ \\
\hline July 1954 & $\mathbf{3} \cdot \mathbf{2 2}$ & $4 \cdot 18$ & $5 \cdot 95$ & $6 \cdot 16$ & $4 \cdot 83$ & $5 \cdot 36$ \\
\hline Aug. 1954 & $3 \cdot 22$ & $4 \cdot 19$ & $7 \cdot 14$ & $7 \cdot 11$ & $3 \cdot 44$ & 4.70 \\
\hline Sept. 1954 & $3 \cdot 13$ & 4.09 & $5 \cdot 82$ & $6 \cdot 70$ & $2 \cdot 94$ & $3 \cdot 04$ \\
\hline Oct. 1954 & $2 \cdot 79$ & $3 \cdot 55$ & $5 \cdot 78$ & $5 \cdot 74$ & $\mathbf{2} \cdot \mathbf{8 8}$ & 3.71 \\
\hline Nov. 1954 & $\mathbf{3} \cdot 26$ & 4,20 & $4 \cdot 98$ & $5 \cdot 23$ & $\mathbf{3} \cdot 69$ & $4 \cdot 43$ \\
\hline Dec. 1954 & $3 \cdot 26$ & $3 \cdot 85$ & $5 \cdot 56$ & $5 \cdot 40$ & $3 \cdot 16$ & $\mathbf{3} \cdot 63$ \\
\hline
\end{tabular}

HHA = horse heart agar; SWA = sea water agar. 
During most months the count obtained by incubation at $0^{\circ}$ was somewhat lower than that obtained at $20^{\circ}$, but the difference is not excessively great and in a few instances the count at $0^{\circ}$ was actually higher than that at $20^{\circ}$.

With few exceptions the counts carried out on sea water agar (SWA) were higher than those obtained with horse heart agar (HHA) in the case of skin and gill samples (Figs. 7-12). Counts of gut samples showed little difference whether SWA or HHA was used.

Table 3. Bacterial counts $\left(0^{\circ}\right.$ incubation $)$ from lemon sole samples

\begin{tabular}{|c|c|c|c|c|c|c|}
\hline & Skin & nt on & $\begin{array}{r}\text { Gut } \\
\text { co } 1\end{array}$ & $\begin{array}{l}\text { tents } \\
\text { on }\end{array}$ & Gills & nt on \\
\hline & HHA & SWA & HHA & SWA & HHA & SWA \\
\hline & $\log \mathrm{co}$ & $1 \mathrm{~cm}^{2}$ & $\log$ & $t / g$. & $\log$ & $\mathrm{t} / \mathrm{g}$. \\
\hline Oct. 1952 & $4 \cdot 17$ & 4.70 & $7 \cdot 22$ & 5.99 & 4.98 & 4.95 \\
\hline Nov. 1952 & $3 \cdot 68$ & $3 \cdot 99$ & 3.00 & $\mathbf{3} \cdot 00$ & $4 \cdot 04$ & $4 \cdot 21$ \\
\hline Dec. 1952 & $4 \cdot 31$ & $4 \cdot 40$ & 4.28 & $4 \cdot 28$ & $4 \cdot 61$ & $4 \cdot 84$ \\
\hline Jan. 1953 & $\mathbf{3} \cdot \mathbf{8 2}$ & 4.00 & $4 \cdot 15$ & $4 \cdot 01$ & $4 \cdot 60$ & $4 \cdot 88$ \\
\hline Feb. 1953 & $3 \cdot 65$ & $3 \cdot 62$ & $3 \cdot 41$ & 4.48 & $4 \cdot 20$ & $4 \cdot 14$ \\
\hline Mar. 1953 & $3 \cdot 79$ & $4 \cdot 18$ & $3 \cdot 30$ & $\mathbf{3} \cdot \mathbf{3 9}$ & 4.09 & $4 \cdot 24$ \\
\hline Apr. 1953 & $3 \cdot 78$ & $3 \cdot 74$ & $5 \cdot 63$ & $5 \cdot 05$ & $4 \cdot 20$ & $4 \cdot 40$ \\
\hline May 1953 & $\mathbf{3 \cdot 4 1}$ & $4 \cdot 12$ & $5 \cdot 72$ & $5 \cdot 55$ & $4 \cdot 21$ & $4 \cdot 21$ \\
\hline June 1953 & $4 \cdot 28$ & $4 \cdot 30$ & $5 \cdot 32$ & $4 \cdot 84$ & $4 \cdot 46$ & $4 \cdot 80$ \\
\hline July 1953 & $3 \cdot 34$ & 4.75 & $2 \cdot 60$ & $5 \cdot 50$ & $4 \cdot 34$ & $4 \cdot 68$ \\
\hline Aug. 1953 & 一 & - & - & - & - & - \\
\hline Sept. 1953 & $4 \cdot 08$ & $4 \cdot 27$ & 6.25 & $6 \cdot 31$ & $4 \cdot 32$ & $4 \cdot 79$ \\
\hline Oct. 1953 & $3 \cdot 89$ & $4 \cdot 20$ & $5 \cdot 56$ & $5 \cdot 91$ & $4 \cdot 75$ & $5 \cdot 07$ \\
\hline Nov. 1953 & $3 \cdot 65$ & $3 \cdot 85$ & 4.20 & 4.04 & $4 \cdot 33$ & $4 \cdot 50$ \\
\hline Dec. 1953 & $3 \cdot 57$ & $3 \cdot 81$ & 4.73 & $4 \cdot 64$ & $5 \cdot 13$ & $5 \cdot 67$ \\
\hline Jan. 1954 & $\mathbf{3} \cdot \mathbf{5 9}$ & 4.03 & $2 \cdot 00$ & $2 \cdot 00$ & $5 \cdot 92$ & $6 \cdot 60$ \\
\hline Feb. 1954 & $\mathbf{3} \cdot \mathbf{3 6}$ & $3 \cdot 64$ & $4 \cdot 16$ & $3 \cdot 22$ & $4 \cdot 27$ & $4 \cdot 43$ \\
\hline Mar. 1954 & $3 \cdot 44$ & $\mathbf{3 \cdot 8 0}$ & $5 \cdot 72$ & $5 \cdot 68$ & 4.72 & $5 \cdot 05$ \\
\hline Apr. 1954 & $2 \cdot 94$ & $3 \cdot 29$ & $5 \cdot 42$ & $5 \cdot 79$ & $4 \cdot 95$ & $5 \cdot 37$ \\
\hline May 1954 & $3 \cdot 70$ & 4.01 & $5 \cdot 21$ & $4 \cdot 46$ & 4.73 & $5 \cdot 20$ \\
\hline June 1954 & $\mathbf{3} \cdot \mathbf{3 8}$ & 3.90 & $5 \cdot 59$ & $5 \cdot 80$ & 4.52 & 4.74 \\
\hline July 1954 & $4 \cdot 15$ & 4.59 & 4.86 & $4 \cdot 89$ & $5 \cdot 40$ & $5 \cdot 66$ \\
\hline Aug. 1954 & $3 \cdot 91$ & $4 \cdot 40$ & $5 \cdot 56$ & $6 \cdot 19$ & 4.65 & $5 \cdot 18$ \\
\hline Sept. 1954 & $2 \cdot 94$ & $3 \cdot 33$ & $4 \cdot 45$ & $5 \cdot 96$ & $4 \cdot 17$ & $4 \cdot 87$ \\
\hline Oct. 1954 & 3.75 & $4 \cdot 11$ & $5 \cdot 39$ & $5 \cdot 06$ & $4 \cdot 18$ & $4 \cdot 62$ \\
\hline Nov. 1954 & $\mathbf{2} \cdot 84$ & $\mathbf{3 \cdot 8 6}$ & $5 \cdot 39$ & $5 \cdot 49$ & $\mathbf{3} \cdot \mathbf{7 2}$ & $4 \cdot 42$ \\
\hline Dec. 1954 & 3.96 & $4 \cdot 14$ & 1.00 & 1.00 & $4 \cdot 21$ & 4.57 \\
\hline
\end{tabular}

Figs. 1-6 show that there was some periodicity in the occurrence of high and low counts during the period of the investigation. Indications of a seasonal recurrence of high and low loads of bacteria on the fish examined are most apparent in the graphs showing the counts on gill samples. Counts at $20^{\circ}$ and $0^{\circ}$ showed similar fluctuations throughout the period of the experiment whether SWA or HHA was used as incubation medium. From the gill counts it appears that bacteria occur in greater number on skate in early summer and early winter, and on lemon sole in mid-winter and possibly again in summer. Unfortunately, owing to the non-availability of the fishing boat at the time, no 
samples were obtained in the latter half of July or in August, 1953. This makes it difficult to assess the importance of the summer maximum which occurred quite clearly in the lemon sole gills count curve for 1954 .

\section{DISCUSSION}

The size of the bacterial populations on the skin and gills and in the gut contents of both skate and lemon sole is within the limits quoted by Shewan (1949) for the normal bacterial load on fresh or living fish. Shewan's figures were derived principally from the results of investigations carried out on 'round' fish, so that it appears that in this respect there is little difference between the bacterial loads on 'round' fish and on flatfish. This finding is somewhat unexpected in view of the much greater populations of bacteria present in bottom deposits as compared with those occurring in the over-lying water (Waksman, 1934). Though it is true that many 'round' fish are demersal feeders, spending much of their time in proximity to the sea bed, they are not exposed to the same degree of contamination as the flatfish which lie directly on the bottom and frequently burrow into the sand or mud deposited there. It seems likely therefore that the similarity between the numbers of bacteria occurring on the two types of fish is due to the selective effect exerted on adventitious bacteria by the conditions of the environment provided by the exposed surfaces of the fish body.

In considering the changes in numbers of bacteria present on flatfish as revealed in this investigation, it is necessary to examine briefly the validity of the count values from the three sample sites as indices of seasonal trends. The value of gut sample counts in assessing the effect of season on the flora of fish is questionable since the bacteria present in the gut are a function of the food ingested rather than of any intrinsic property of the fish. Thus several workers have established that in non-feeding fish the gut is virtually sterile (see Margolis, 1953); this has been confirmed in the present investigation in the case of lemon sole, many of which do not feed during the December-February period. Though feeding habits are related to the spawning cycle in lemon sole and are therefore, to some extent, seasonal this is not so in the case of skate. Nevertheless, the curve of skate gut counts shows more evidence of periodicity than that of lemon sole and so it seems that such curves are not simply bacterial records of feeding habits. Possibly some physiological change in the fish, which may or may not be seasonal, is responsible. In any case the protected situation of the gut flora makes it somewhat insensitive to seasonal changes in the environment of the fish and for this reason alone it is unlikely to be a good indicator of overall seasonal effects.

Skin counts, while showing a tendency to fluctuate more or less regularly with season, do not present any very clear-cut picture. This is most probably due to the effect on the bacterial flora of the fish of the catching procedure, in the course of which the animals are swept along over the bed of the ocean and tumbled against each other and against rocks, ropes, etc. Such treatment must appreciably alter the numbers of bacteria on the skin of the fish, and for this 
reason the results obtained from skin samples, while acceptable as providing an indication of the actual variation in the bacterial population of the living fish, cannot be accepted as accurately describing these variations.

The counts on gill samples are considered to represent most nearly the true state of the bacterial population on a living fish. The gills, fully exposed to the aqueous environment of the free-swimming fish, are largely protected from the effects of the trawling operation when the fish is caught and it seems probable that the numbers of viable bacteria present on the gills are much the same before and after capture. Thus the pattern of seasonal variation so clearly delineated in the curves derived from the gill counts is considered to represent the actual changes on the living fish fairly accurately.

The difference in the shapes of the corresponding gill counts curves for skate and lemon sole indicates that, despite the overall quantitative similarity in the bacterial populations of different types of fish, species is of some importance in determining the concomitant bacterial population.

The seasonal occurrence of large numbers of bacteria in the sea has been thought by some workers to be correlated with either maximum water temperatures (ZoBell \& Feltham, 1934) or with plankton outbursts (Lloyd, 1930; ZoBell \& McEwan, 1935). The temperature of a fish is dependent on that of the surrounding water so that, if temperature is the factor of greatest importance in determining the bacterial population of sea water, it is likely to be of similar importance in the case of fish. However, no coincidence of high water temperatures with high bacterial loads on fish was observed in this investigation and temperature does not, therefore, appear to constítute the main determinative factor in this respect. The seasonal outbursts of plankton are limited during their period of growth to the surface layers of the sea and it would seem unlikely on a first estimate that they would affect the bacterial flora of flatfish which live exclusively at the bottom of the sea. Nevertheless, it was observed that highest counts were obtained from fish caught some 2 months after the spring and autumn plankton outbursts. In Aberdeen Bay during the period of the investigations the outbursts occurred in March and September in 1953 and in early March and early September in 1954 (Dr J. H. Fraser, personal communication) and this can be seen to correlate with the incidence of maxima in Figs. 3 and 6 in the way described above.

After the peak of plankton growth has passed, the decaying remains of the constituent plants and animals fall slowly to the bottom of the sea where they provide an additional source of organic nutrients for the bacteria growing there and also add a new quota of bacteria to this population, consisting of the organisms associated with the decaying particles. It seems likely that in such conditions there would be an appreciable increase in the numbers of bacteria present in the bottom flora, and in particular an increase of those types of bacteria best adapted for the breakdown of organic material of marine origin. Such bacteria are, by their biochemical capabilities, extremely well suited for life on the surfaces of fish, where a plentiful supply of organic nutrients is abundantly available, and an increase in the size of bacterial population on fish would be expected to occur in association with an increase in their 


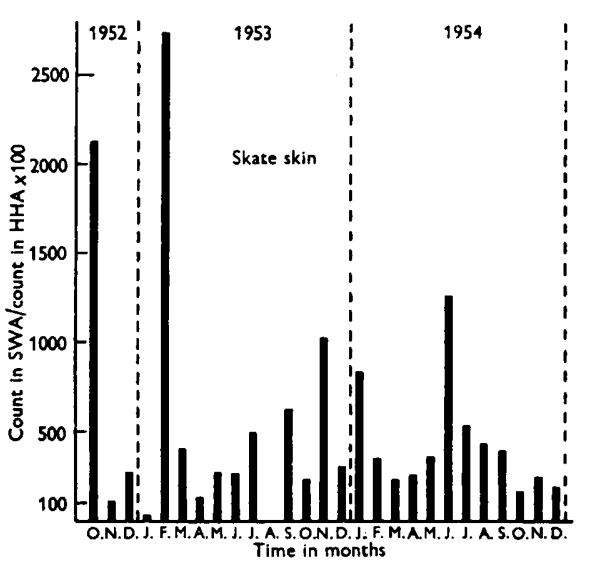

Fig. 7

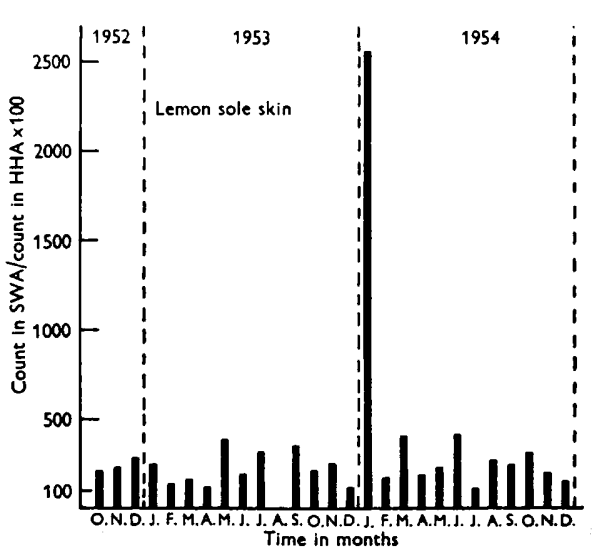

Fig. 10

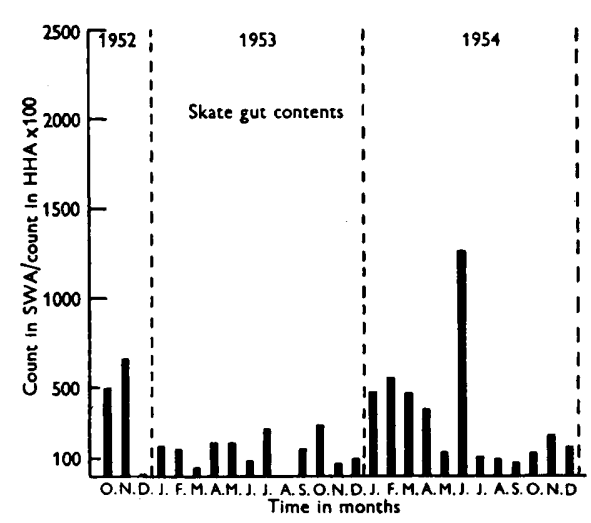

Fig. 8

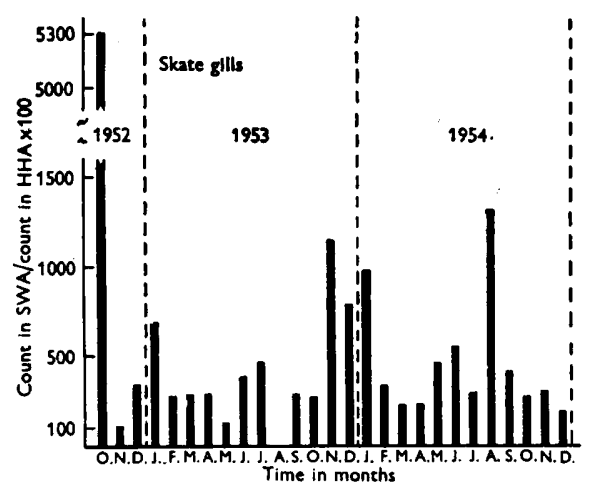

Fig. 9

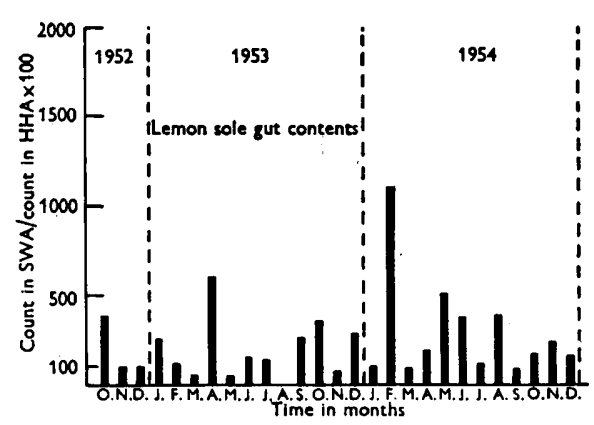

Fig. 11

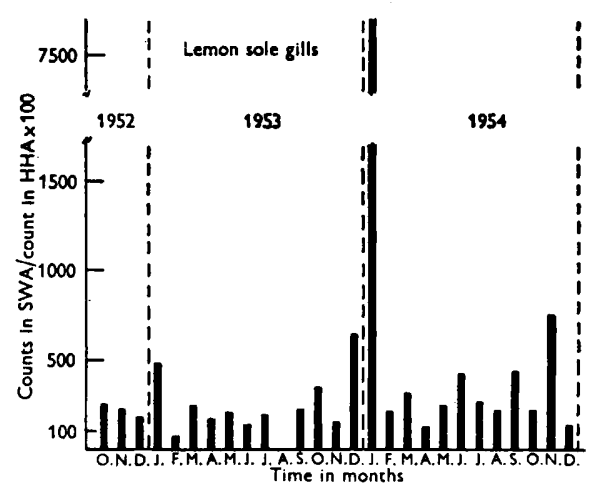

Fig. 12

Figs. 7-9. Skate skin, gut contents, gills, respectively. Count in sea water agar (SWA) as a percentage of count in horse heart agar (HHA). Incubation temperatures: $20^{\circ}$.

Figs. 10-12. Lemon sole skin, gut contents, gills, respectively. Count in sea water agar (SWA) as a percentage of count in horse-heart agar (HHA). 
numbers, in the immediate environment. It seems probable therefore that the seasonal variation in the bacterial population of flatfish is determined, though indirectly, by the occurrence of plankton outbursts. Counts carried out at $20^{\circ}$ and $0^{\circ}$ showed practically identical variations during the course of the experiment, though the relative proportions of the flora appearing at the two temperatures were not constant. This indicates that the seasonal effect is probably exerted impartially on the total bacterial flora.

The high incidence of organisms growing at $0^{\circ}$ among the bacteria from flatfish is in accord with the view that most fish bacteria are more or less psychrophilic (Shewan, 1949) and the very low counts obtained with $37^{\circ}$ as incubation temperature confirm this viewpoint. It is probable, however, that the temperature relations of bacteria from fish are to some extent a function of the temperature of the sea water in which the fish live. Thus Wood (1953) recorded that a high proportion of the bacteria isolated from marine sources in warm Australian waters grow at $37^{\circ}$.

The results expressed as block diagrams in Figs. 7-12 represent the counts in SWA medium expressed as percentages of the corresponding counts in HHA medium. They demonstrate clearly the superiority of SWA as a medium for carrying out bacterial counts on fish except for counts on gut samples. In gut samples it was commonly found that the bacterial population consisted almost entirely of a culture of a single well-defined type of micro-organism which, though growing well in the presence of sea water, preferred a rather richer medium than SWA (Liston, 1954). Nevertheless, it appears from the skin and gill counts that there is a group of micro-organisms on fish, constituting a significant part of the total flora, which are sea water-loving or even nutritionally exacting for sea water. ZoBell and his co-workers have repeatedly claimed that there exists a specific marine bacterial flora (ZoBell \& Upham, 1944; Zobell, 1946), the most definite characteristic of which is a requirement for sea water for growth on initial isolation. While most of the organisms isolated by the present writer from fish have proved to be able to grow on tapwater media either on initial isolation or after a primary culture on sea-water media, many certainly show a marked preference for the latter, both from the point of view of rapidity of growth and also quantity of growth. It is interesting that Wood (1953), though disinclined to support the hypothesis that a specific marine flora exists, recorded that bacterial counts on samples from 'truly oceanic stations', were four times as high on sea water agar as on fresh water agar. Thus is would appear that there is a bacterial flora in the sea, well adapted to the environmental conditions and in consequence more or less exacting, nutritionally, for sea water or some of the constituents of sea water (McLeod, Onofrey \& Norris, 1954). The results described above indicate that the bacteria on fish belong to species encountered in the open sea. Whether the bacterial flora of the fish is a function of that of the surrounding sea water or vice versa it is not possible to decide at present; in view of the low nutrient content of sea water it is probable that the sea will play a passive role, acting merely as a vehicle of transport for bacteria derived from suitable sites of growth in the marine environment. 
I wish to express my gratitude to Dr J. H. Fraser of the Marine Laboratory, Aberdeen, who provided me with information on plankton outbursts.

The work was carried out as part of the programme of the Food Investigation Organization of the Department of Scientific and Industrial Research.

\section{REFERENCES}

Anderson, A. G. (1907). On the decomposition of fish. 26th Ann. Rep. Fish Bd Scot. Part III, Scientific Investig., 13.

Harrison, F. C., Perry, M. \& Smith, R. (1926). The bacteriology of certain sea fish. Rep. nat. Res. Coun. Can. no. 19.

Liston, J. (1954). A group of luminous and non-luminous bacteria from the intestine of flatfish. J. gen. Microbiol. 12, i.

Lloyd, B. (1930). Bacteria of the Clyde Sea area: a quantitative investigation. J. Mar. Biol. Ass. (N.S.). 16, 879.

Margolis, L. (1953). The effect of fasting on the bacterial flora of the intestine of fish. J. Fish. Res. Bd Can. 10, 62.

McLeod, R., ONOFrey, E. \& Norris, M. E. (1954). Nutrition and metabolism of marine bacteria. 1. Survey of nutritional requirements. J. Bact. 68, 680.

Proctor, B. E. \& Nickerson, J. R. T. (1935). An investigation of the sterility of fish tissues. J. Bact. 30, 377 .

Reay, G. A. \& Shewan, J. M. (1949). The spoilage of fish and its preservation by chilling. Advance. Food Res. $2,343$.

SchönBerg, F. (1930). Über die Fischfaulnis und ihre bacteriologische Diagnose. Berl. tierärztl. Wschr. 44, 429.

Shewan, J. M. (1949). Some bacteriological aspects of handling, processing and distribution of fish. J. Roy. San. Inst. 69, 394.

Waksman, S. A. (1934). The distribution and conditions of existence of bacteria in the sea. Ecological Monographs, 4, 523.

Wood, E. J. F. (1953). Heterotrophic bacteria in marine environments of Eastern Australia. Aust. J. Mar. Freshw. Res. 4, 160.

ZoBell, C. E. (1946). Marine Microbiology, 17. Waltham, Mass., U.S.A.: Chronica Botanica.

ZoBell, C. E. \& Feltham, C. B. (1934). Preliminary studies on the distribution and characteristics of marine bacteria. Bull. Scripps Instn Oceanogr., tech. 3, 279.

ZoBell, C. E. \& McEwan, G. E. (1935). The lethal action of sunlight upon bacteria in sea water. Biol. Bull., Woods Hole, 68, 93.

ZoBeli, C. E. \& UphaM, H. C. (1944). A list of marine bacteria including descriptions of 60 new species. Bull. Scripps Instn Oceanogr. 5, 239. 